\title{
DAMPAK NIKAH SIRI TERHADAP ISTERI DAN ANAK
}

\author{
Farida Prihatin ${ }^{1}$
}

\section{Abstrak}

This article gives enlightenment conecerning nikah siri (unregistered marriage), in Indonesia. The purpose of this nikah siri is a marriage conducted in accordance with the provisions of religious harmony and fulfill the requirements of marriage as prospective bridegroom and women, guardians, consent granted, witnesses and consent of both prospective bride and the dowry, but not executed before the Marriage registration office. Siri marriage is usually performed before the local (moslem) clergy. Nikah siri reasons this done many things, among others, to avoid fornication, still bound by employment contracts that prohibit she was married to a specified period or to be polygamous because they do not obtain consent from his wife or his wives, and can also be due to lack of fees to pay marriage registration fees. This siri marriage because marriage is not done then the recording has no legal force, because no country legally valid marriage even be considered this never happened. The impact of this siri marriage are felt on the wife and children. Both the wife and children have no legal relationship with her husband/father. So the wife does not have rights that should be owned by the wife of a valid marriage. So also with the child, the child status is not lawful because the child is born not from a legitimate marriage, and children have had only a civil relationship with his mother, as a result he/she can not obtain the rights that they should get if he/she was born of a valid marriage according to both valid under islamic and country law. Based on those reasons the author conclude that siri marriage is very harmful and does not provide legal protection to the wife and children.

Kata kunci: hukum islam, nikah siri, pencatatan perkawinan.

\section{Pendahuluan}

Manusia sebagai mahluk sosial diciptakan oleh Allah SWT untuk hidup bersama, saling membutuhkan, dan saling tolong menolong. Sudah

1 Penulis adalah Staf Pengajar untuk mata kuliah Hukum Perorangan dan Kekeluargaan Islam pada Fakultas Hukum Universitas Indonesia. Alamat korespondensi: farida.prihatini@yahoo.co.id. 
menjadi fitrah manusia bahwa antara seorang laki-laki dan seorang perempuan dapat terjadi suatu daya saling tarik menarik satu sama lain yang akhirnya berujung pada keinginan untuk hidup bersama. Agar hubungan ini menjadi halal dibuatlah suatu lembaga yang bernama lembaga perkawinan. Hal ini sesuai dengan firman Allah dalam Qur'an Surat (selanjutnya disebut Q.S.) an-Najm (53): 45 yang terjemahannya: "dan sesungguhnya Dialah yang menciptakan pasangan laki-laki dan perempuan". 2

Selanjutnya dalam Q.S. ar- Ruum (30): 21 dikatakan:

Dan di antara tanda-tanda kekuasaan-Nya ialah Dia menciptakan untukmu isteri-isteri dari jenismu sendiri, supaya kamu cenderung dan merasa tenteram kepadanya, dan dijadikan-Nya di antaramu rasa kasih sayang. Sesungguhnya pada yang demikian itu benar-benar terdapat tanda-tanda bagi kaum yang berpikir. ${ }^{3}$

Berdasarkan firman Allah SWT ini terlihat Allah menciptakan manusia berpasang-pasangan laki-laki dan perempuan serta dijadikannya perjodohan untuk membentuk keluarga melalui perkawinan. Keluarga merupakan satuan sosial masyarakat terkecil yang sangat menentukan atau pilar utama dalam pembangunan masyarakat. Jika pilar utama ini berdiri dengan kokoh di atas landasan yang benar tentu masyarakatnya akan baik dan kuat. Mengingat pentingnya perkawinan ini maka pemerintah sangat memperhatikan lembaga ini terbukti dengan diundangkannya Undang Undang Nomor 1 Tahun 1974 tentang Perkawinan dan diberlakukannya Peraturan pemerintah Nomor 9 Tahun 1975 sebagai peraturan pelaksanaannya. Menurut undang undang ini perkawinan dapat dikatakan sah apabila dilakukan menurut hukum agama dan kepercayaannya, sebagaimana diatur dalam Pasal 2 ayat (1). Selanjutnya pada ayat (2) dikatakan bahwa tiap perkawinan dicatat menurut peraturan perundang-undangan yang berlaku. Khusus bagi umat Islam di Indonesia masalah perkawinan ini juga diatur dalam Kompilasi Hukum Islam (selanjutnya disebut KHI). Dalam Pasal 5 ayat (1) dikatakan bahwa perkawinan harus dicatat agar terjamin ketertiban perkawinan. Namun demikian walaupun sudah diatur mengenai pencatatan perkawinan ini masih banyak terjadi perkawinan yang tidak dicatat yang lebih dikenal dengan nama nikah siri atau nikah di bawah tangan. Nikah siri 2006), hal. 54.

${ }^{2}$ Departemen Agama, “Al-Qur'an dan Terjemahannya”, (Jakarta: Cahaya Qur'an,

${ }^{3}$ Ibid., hal. 406 . 
ini jika dilakukan sesuai dengan rukun dan syarat perkawinan maka secara hukum agama perkawinan ini adalah sah. Walaupun sah secara agama tapi tidak mempunyai kekuatan hukum. Dikatakan tidak mempunyai kekuatan hukum karena tidak dicatatkan pada Pegawai Pencatat Nikah sehingga perkawinan itu tidak dapat dibuktikan secara hukum negara telah terjadi. Keadaan ini berakibat tidak adanya hubungan hukum antara suami dengan isteri dan anaknya. Tentu saja ini sangat merugikan isteri dan anak-anak yang dilahirkan dalam perkawinan tersebut. Dalam pembahasan akan ditelaah apabila dilakukan pernikahan siri bagaimana kedudukan isteri dan anak dalam perkawinan dan apa jalan keluarnya agar perkawinan siri ini tidak saja sah menurut agama namun juga sah menurut hukum negara.

\section{Dampak Nikah Siri Bagi Isteri dan Anak}

\section{A. Pengertian Perkawinan}

Perkawinan dalam pandangan Islam, bukan hanya sekedar formalisasi hubungan suami isteri, pergantian status, serta upaya pemenuhan kebutuhan fitrah manusia. Perkawinan bukan hanya sekedar upacara sakral yang merupakan bagian dari daur kehidupan manusia. Perkawinan merupakan bukti ketundukan seseorang kepada Allah dan Rasul-Nya. Perkawinan merupakan salah satu perbuatan hukum yang dapat dilaksanakan oleh mukallaf (cakap) yang memenuhi syarat. Ta'rif (pengertian) perkawinan menurut hukum Islam adalah pernikahan, yaitu akad yang sangat kuat (miitsaaqan ghaaliizhaan) untuk mentaati perintah Allah dan melaksanakannya merupakan ibadah, yang bertujuan untuk mewujudkan kehidupan rumah tangga yang sakinah, mawaddah dan rahmah. ${ }^{4}$

Rumah tangga yang baik menurut agama Islam adalah rumah tangga yang pergaulan suami isteri dilandasi dengan ma'ruf, sakinah, mawaddah dan rahmah.

Ma'ruf berarti di dalam pergaulan suami-isteri harus saling menghormati dan saling menjaga rahasia masing-masing. Haram hukumnya jika suami- membuka rahasia isterinya dan begitu pula sebaliknya. Ditegaskan dalam surat an-Nisaa ayat 34 yang terjemahannya: Isteri yang baik-baik ialah isteri yang tunduk kepada

4 Syeikh Zainuddin bin Abdul Aziz Al Malibary, "Fatchul Mu'in", Jilid 3, diterjemahkan oleh Aliy As'ad, (Kudus: Menara Kudus, 1979), hal. 1. 
Tuhan dan memelihara rumah tangganya dan rahasia suami serta rahasia keluarga. ${ }^{5}$

Dalam sebuah Hadits yang diriwayatkan oleh Muslim, Rasul berkata:

Bahwa sesungguhnya di antara yang paling dimarahi Tuhan nanti di hari kiamat, ialah seorang suami yang diberitahu oleh isterinya tentang rahasia isteri itu, sedangkan oleh suami tadi rahasia itu disiarkan; begitupun seorang isteri yang diberitahu oleh suaminya tentang rahasia suami itu sedang oleh isteri itu rahasia tadi disiarkannya. ${ }^{6}$

Sakinah berarti di dalam kehidupan rumah tangga terdapat keamanan dan ketentraman serta menjauhkan diri dari perselisihan antara suami isteri. Mawaddah berarti suami isteri di dalam kehidupan rumah tangga harus saling mencintai yang meliputi arti saling memerlukan dalam hubungan seks. Biasanya hubungan ini lebih sering dilakukan pada saat masih muda dan lama-lama berkurang di saat usia mulai mendekati senja.

Rahmah berarti adanya saling menyantuni, saling membela dan saling memerlukan pada pasangan suami isteri, terutama disaat masa tua. $^{7}$

Hubungan suami isteri yang memenuhi keempat unsur tersebut adalah hubungan suami isteri yang diharapkan oleh agama Islam.

Perkawinan atau pernikahan dalam literatur fiqh berbahasa Arab disebut dengan dua kata, yaitu nikah dan zawaj. Kedua kata ini yang terpakai dalam kehidupan sehari-hari orang Arab dan banyak terdapat dalam Al-Qur'an dan hadits Nabi. Kata na-ka-ha banyak terdapat dalam Al-Qur'an dengan arti kawin, seperti dalam surat an-Nisa' ayat $3 .^{8}$

Dan jika kamu takut tidak akan dapat berlaku adil terhadap (hak-hak) perempuan yang yatim (bilamana kamu

5 Sayuti Thalib, "Hukum Kekeluargaan Indonesia Berlaku bagi Umat Islam", (Jakarta: UI Press, 1986), hal. 74.

${ }^{6}$ Ibid., mengutip T.M. Hasbi Ash-Shiddieqy dalam al-Islam (1971), hal. 621.

${ }^{7}$ Ibid., hal. 73-75.

${ }^{8}$ Amir Syarifuddin, "Hukum Perkawinan Islam di Indonesia", (Jakarta: Kencana, 2007), hal. 35 . 
mengawininya), Maka kawinilah wanita-wanita (lain) yang kamu senangi : dua, tiga atau empat. Kemudian jika kamu takut tidak akan dapat berlaku adil, Maka (kawinilah) seorang saja, atau budak-budak yang kamu miliki. yang demikian itu adalah lebih dekat kepada tidak berbuat aniaya. (QS. An-Nisa (4): 3) ${ }^{9}$

Secara arti kata nikah berarti "bergabung", "hubungan kelamin" dan juga berarti "akad". Adanya dua kemungkinan dua arti ini karena kata nikah yang terdapat dalam Al-Qur'an memang mengandung dua arti tersebut. ${ }^{10}$

Undang-Undang (UU) Perkawinan di Indonesia dalam Pasal 1 merumuskan perkawinan sebagai ikatan lahir batin antara seorang pria dengan seorang wanita sebagai suami istri dengan tujuan membentuk keluarga (rumah tangga) yang bahagia dan kekal berdasarkan Ketuhanan Yang Maha Esa.

Berdasarkan rumusan Pasal 1 di atas dapat kita simpulkan beberapa hal, yaitu: ${ }^{11}$

Pertama: digunakannya kata "seorang pria dengan seorang wanita" mengandung arti bahwa perkawinan itu hanyalah antara jenis kelamin yang berbeda. Hal ini menolak perkawinan sesama jenis yang mulai dilegalkan oleh beberapa negara.

Kedua: digunakannya ungkapan "sebagai suami istri" mengandung arti bahwa perkawinan itu adalah bertemunya dua jenis kelamin yang berbeda dalam suatu rumah tangga, bukan hanya dalam istilah "hidup bersama".

Ketiga: dalam definisi tersebut disebutkan pula tujuan perkawinan yaitu membentuk rumah tangga yang bahagia dan kekal, yang menafikan sekaligus perkawinan temporal sebagaimana yang berlaku dalam perkawinan mut' $a h^{12}$ dan perkawinan tahlil. ${ }^{13}$

${ }^{9}$ Departemen Agama Republik Indonesia, Op. Cit., (Jakarta: Al-Huda, 2005), hal.

78.

${ }^{10}$ Op Cit., hal. 36.

${ }^{11}$ Ibid., hal. 40.

${ }^{12}$ Nikah mut'ah adalah kawin sementara atau nikah terputus lebih dikenal dengan kawin kontrak yaitu seorang laki-laki mengadakan akad dengan seorang perempuan untuk waktu tertentu, misalnya seminggu, sebulan. Dinamakan mut'ah karena laki-laki tersebut memanfaatkan dan menikmati perkawinan serta bersenang-senang hingga tempo yang telah dientukan waktunya pada saat atau sebelum akad. Imam mazhab sepakat tentang 
Keempat: disebutkannya berdasarkan Ketuhanan Yang Maha Esa menunjukkan bahwa perkawinan itu bagi Islam adalah peristiwa agama dan dilakukan untuk memenuhi perintah agama.

Kompilasi Hukum Islam di Indonesia Pasal 2 memberikan definisi lain yang tidak mengurangi arti-arti definisi UU Perkawinan tersebut, namun bersifat menambah penjelasan, dengan rumusan sebagai berikut:

Perkawinan menurut Islam adalah pernikahan, yaitu akad yang sangat kuat atau miitsaaqan ghaliizhaan untuk mentaati perintah Allah dan melaksanakannya merupakan ibadah.

Ungkapan: akad yang sangat kuat atau miitsaaqan ghailizhaan merupakan penjelasan dari ungkapan "ikatan lahir batin" yang terdapat dalam rumusan UU Perkawinan yang mengandung arti bahwa akad perkawinan itu bukanlah semata perjanjian yang bersifat keperdataan. Pernikahan merupakan akad yang sangat kuat (miitsaaqan ghaaliizhaan) untuk mentaati perintah Allah dan melaksanakannya merupakan ibadah, yang bertujuan untuk mewujudkan kehidupan rumah tangga sakinah, mawaddah, dan rahmah. ${ }^{14}$ Dapat dikatakan dalam perkawinan ikatan antara suami istri adalah ikatan yang paling suci dan paling kuat. Sifat kesucian dan kuat ini oleh Allah dalam al-Qur'an disebut "Miitsaaqan ghaaliizhaan", perjanjian yang kokoh. Hal ini dijelaskan pada Q.S. an-Nisa (4) ayat 21 yang terjemahannya:

Bagaimana kamu akan mengambilnya kembali, padahal sebagian kamu telah bergaul (bercampur) dengan yang

keharamannya berdasarkan Hadits yang diriwayatkan oleh Ibnu Majah, Rasullah SAW mengharamkan mut'ah dan bersabda: Hai sekalian manusisa, pernah kuizinkan kalian melakukan kawin mut'ah. Ketahuilah sesungguhnya Allah telah mengharamkan hingga hari kiamat. Lihat Totok Jumantoro dan Samsul Munir Amin dalam "Kamus Ilmu Ushul Fikih", (Jakarta: Amzah, 2005), hal. 259.

${ }^{13}$ Nikah tahlil adalah seorang wanita menikah dengan seorang laki-laki dengan tujuan agar ia dapat kembali kepada mantan suaminya yang telah menjatuhkan talak tiga pada dirinya. Jika suami menjatuhkan talak tiga, maka suami yang telah menjatuhkan talak tiga pada istrinya, maka ia tidak dapat menikah kembali dengan mantan istrinya kecuali mantan istrinya menikah kembali dengan orang lain dan telah $b a^{\prime} d a$ dukhul atau telah melakukan hubungan badan baru bercerai. Dikatakan muhallil karena menghalalkan perkawinan yang telah jatuh talak tiga.

${ }^{14}$ Neng Djubaedah, et al, "Hukum Perkawinan Islam di Indonesia", (Jakarta: Hecca Publishing dan FHUI, 2005), hal. 33. 


\section{lain sebagai suami isteri. Dan mereka (isteri-isterimu) telah mengambil dari kamu perjanjian yang kuat. $^{15}$}

Ungkapan untuk menaati perintah Allah dan melaksanakannya merupakan ibadah, merupakan penjelasan dari ungkapan "berdasarkan Ketuhanan Yang Maha Esa" dalam UU Perkawinan. Hal ini lebih menjelaskan bahwa perkawinan bagi umat Islam merupakan peristiwa agama dan oleh karena itu orang yang melaksanakannya telah melakukan perbuatan ibadah. ${ }^{16}$

\section{B. Syarat Sahnya Perkawinan}

Menurut hukum Islam perkawinan baru dapat dikatakan sah apabila telah memenuhi rukun dan syarat perkawinan. Rukun adalah unsur merupakan bagian tak terpisahkan dari suatu perbuatan atau lembaga yang menentukan sah atau tidaknya perbuatan tersebut dan ada atau tidak adanya sesuatu. Sedangkan syarat bukan merupakan bagian yang terdapat dalam suatu perbuatan, tetapi di luar perbuatan tersebut. Namun demikian baik rukun maupun syarat tetap menentukan sah atau tidaknya suatu perbuatan.

Rukun nikah merupakan bagian dari hakekat perkawinan, artinya bila salah satu rukun nikah tidak terpenuhi maka tidak terjadi suatu perkawinan.

\section{Rukun Perkawinan}

a. Calon mempelai laki-laki dan perempuan.

b. Wali bagi calon mempelai perempuan. ${ }^{17}$

c. Saksi, minimal 2 (dua) orang laki-laki.

d. Ijab kabul. ${ }^{18}$

15 Al-Qur'an dan Terjemahannya, Op.Cit., hal. 120.

${ }^{16}$ Amir Syarifuddin, Op. Cit., hal. 41.

17 Wali adalah seseorang yang bertindak atas nama mempelai perempuan dalam suatu akad nikah. Akad nikah dilakukan oleh dua pihak, yaitu pihak laki-laki yang dilakukan oleh mempelai laki-laki itu sendiri dan mempelai perempuan yang dilakukan oleh walinya. Lihat Amir Syarifuddin, Op. Cit., hal. 69.

${ }^{18}$ Ijab yaitu penegasan kehendak untuk mengikatkan diri dalam perkawinan dan dilakukan oleh pihak perempuan ditujukan kepada calon suami. Sedangkan kabul yaitu penegasan penerimaan pengikatan diri sebagai suami isteri yang dilakukan pihak laki-laki. 
Ketentuan ini sama dengan ketentuan yang diatur dalam Pasal 14 Kompilasi Hukum Islam. Dalam pasal ini dikatakan bahwa untuk melaksanakan perkawinan harus ada: a. Calon suami; b. Calon isteri; c. Wali nikah; d. Dua orang saksi dan e. Ijab dan Kabul.

\section{Syarat Perkawinan}

\section{a. Syarat Umum}

Perkawinan tidak boleh bertentangan dengan larangan perkawinan dalam al-Qur'an yang termuat dalam QS. AlBaqarah(2):221 tentang larangan perkawinan karena perbedaan agama, QS. An-Nisa(4):22,23,24 tentang larangan perkawinan karena hubungan darah, semenda dan saudara sesusuan. Kompilasi Hukum Islam juga mengatur hal ini dalam Pasal 39 yang mengatur larangan perkawinan karena pertalian nasab, pertalian kerabat semenda dan karena pertalian sesusuan.

\section{b. Syarat Khusus}

1) Adanya calon mempelai laki-laki dan perempuan.

2) Harus ada persetujuan bebas antara kedua calon mempelai. Perkawinan pada dasarnya tidak boleh dipaksakan. Pada masa Rasulullah ada seorang wanita datang kepada Nabi Muhammad SAW dan menceritakan bahwa bapaknya telah mengawinkannya dengan seorang laki-laki, sedangkan ia tidak mau (tidak suka), maka Nabi menyerahkan keputusan itu kepada gadis itu, apakah mau meneruskan perkawinan itu atau minta cerai. ${ }^{19}$ Ketentuan Hadits ini diikuti oleh Pasal $16 \mathrm{KHI}$ ayat (1) yang menyatakan bahwa perkawinan harus didasarkan atas persetujuan kedua calon mempelai.Pernyataan persetujuan ini dalam Pasal 16 ayat (2) dikatakan dapat berupa pernyataan tegas dan nyata dalam tulisan, lisan atau

Pelaksanaan antara pengucapan ijab dan kabul harus jelas dan tidak boleh ada jeda waktu, harus segera dijawab.

${ }^{19}$ Mohd. Idris Ramulyo, "Hukum Perkawinan Islam Suatu Analisis dari Undang Undang No. 1 Tahun 1974 dan Kompilasi Hukum Islam", cet. 5, (Jakarta: Bumi Aksara , 2004), hal. 51. 
isyarat, dapat juga berupa diam dalam arti selama tidak ada penolakan yang tegas.

3) Harus ada wali nikah.

4) Saksi.

5) Mahar.

Mahar merupakan kewajiban yang harus dibayar oleh calon mempelai laki-laki kepada calon mempelai perempuan. Hal ini ditegaskan dalam Q.S. an-Nisaa (4): 4 yang artinya:

Dan berikanlah maskawin (mahar) kepada perempuan (yang kamu nikahi) sebagai pemberian yang penuh kerelaan. Kemudian, jika mereka menyerahkan kepada kamu sebagian dari (maskawin) itu dengan senang hati, maka terimalah dan nikmatilah pemberian itu dengan senang hati. ${ }^{20}$

Mas kawin merupakan lambang kesiapan dan kesediaan suami untuk memberi nafkah lahir kepada isteri dan anakanaknya, dan selama maskawin itu bersifat lambang, maka sedikitpun tidak apa. ${ }^{21}$ Pemberian mahar bukan dilihat dari besarnya nilai mahar yang diberikan melainkan dari keikhlasan memberi sebagai tanda cinta dan kasih sayangnya pada calon mempelai wanita. Perkawinan bukan jual beli dan mahar bukan harga seorang wanita. Semakin ringan maskawin maka semakin baik maskawinnya. Mahar adalah salah satu komponen untuk menghalalkan perkawinan, karenanya jangan memberatkan calon mempelai pria dengan meminta mahar yang mahal, yang tidak dapat dipenuhinya.

Firman Allah SWT di atas diikuti oleh KHI dalam Pasal 30 yang berbunyi bahwa calon mempelai pria wajib membayar mahar kepada calon mempelai wanita yang jumlah, bentuk dan jenisnya disepakati oleh kedua pihak. Dijelaskan lebih lanjut dalam Pasal 31 bahwa penentuan mahar berdasarkan asas kesederhanaan dan kemudahan yang dianjurkan oleh ajaran

\footnotetext{
${ }^{20}$ Departemen Agama, Op.Cit. hal. 77.

${ }^{21}$ M. Quraish Shihab, "Wawasan Al-Quran", (Bandung: Mizan, 2004), hal. 204.
} 
Islam.Pemberian mahar ini diberikan langsung kepada calon mempelai wanita dan sejak itu menjadi haknya (Pasal 32)

6) Ijab Kabul.

Sedangkan menurut Undang-Undang Nomor 1 Tahun 1974 Tentang Perkawinan dalam Pasal 2 ayat (1) menyatakan bahwa perkawinan adalah sah apabila dilakukan menurut hukum masingmasing agamanya. Dalam penjelasan Pasal 2 dikatakan bahwa tidak ada perkawinan di luar hukum masing-masing agamanya. Syarat sah perkawinan menurut Undang-Undang Perkawinan diatur dalam Pasal 6 sampai dengan Pasal 10. Syarat- syarat tersebut adalah:

1. Ada persetujuan kedua calon mempelai (Pasal 6)

2. harus berusia 16(enam belas) tahun bagi wanita dan berusia 19(sembilanbelas) tahun bagi pria (Pasal 7)

3. Tidak terikat tali perkawinan dengan orang lain kecuali dalam hal yang diijinkan (Pasal 9)

4. Bagi yang belum berusia 21(dua puluh satu) tahun harus mendapat izin kedua orang tua (Pasal 6 ayat (2))

5. Tidak merupakan pihak-pihak yang dilarang untuk menikah sebagaimana diatur dalam Pasal 8:

(a). berhubungan darah dalam garis keturunan lurus ke bawah atau pun ke atas;

(b). berhubungan darah dalam garis keturunan menyamping yaitu antara saudara, antara saudara dengan orang tua dan antara seorang dengan saudara neneknya;

(c). berhubungan semenda, yaitu mertua, anak tiri, menantu dan ibu/bapak tiri;

(d). berhubungan sesusuan, yaitu orang tua sesusuan, anak sesusuan, saudara sesusuan dan bibi/paman sesusuan;

(e). berhubungan saudara dengan istri atau sebagai bibi atau kemenakan dari istri, dalam hal seorang suami beristri lebih dari seorang;

(f). mempunyai hubungan yang oleh agamanya atau teraturan lain yang berlaku, dilarang kawin.

\section{Pencatatan Perkawinan}

Di Indonesia baik Undang Undang Perkawinan maupun Kompilasi Hukum Islam mengharuskan pencatatan perkawinan. Dalam Undang Undang Perkawinan dikatakan dalam Pasal 2 ayat 
(1) perkawinan baru dapat dikatakan sah apabila dilakukan menurut hukum masing-masing agamanya dan kepercayaannya itu. Selanjutnya pada ayat (2) dikatakan bahwa tiap-tiap perkawinan dicatat menurut peraturan perundang-undangan yang berlaku. Penjelasan atas pasal ini menjelaskan bahwa tidak ada perkawinan di luar hukum masing-masing agamanya dan kepercayaannya itu, sesuai dengan Undang Undang Dasar 1945. Maksud dari hukum masing-masing agamanya dan kepercayaannya itu termasuk ketentuan perundang-undangan yang berlaku bagi golongan agamanya dan kepercayaannya itu sepanjang tidak bertentangan atau tidak ditentukan lain dalam Undang- undang ini.

Pencatatan perkawinan ini dalam Penjelasan Umum sub 3 Undang Undang Perkawinan merupakan salah satu asas perkawinan, yaitu asas perkawinan terdaftar. Tiap-tiap perkawinan yang dilakukan menurut hukum masing-masing agamanya dan kepercayaannya itu akan dianggap mempunyai kekuatan hukum bilamana dicatat menurut peraturan perundangundangan yang berlaku, sebagaimana ditegaskan dalam Pasal 2 ayat (2) Undang Undang Perkawinan. ${ }^{22}$ Dijelaskan pula bahwa pencatatan perkawinan ini sama halnya dengan pencatatan peristiwa-peristiwa penting dalam kehidupan seseorang, misalnya kematian, kelahiran yang dinyatakan dalam surat-surat keterangan, suatu akte resmi yang juga dimuat dalam daftar pencatatan.

Sedangkan dalam Kompilasi Hukum Islam mengenai pencatatan perkawinan diatur dalam Pasal 5 yang mengatur untuk ketertiban perkawinan bagi orang Islam setiap perkawinan harus dicatat. Dan pada ayat (2) dikatakan bahwa pencatatan itu dilakukan oleh Pegawai Pencatat Nikah sebagaimana diatur dalam Undang Undang Nomor 22 Tahun 1946 jo Undang Undang Nomor 32 Tahun 1954. Pegawai Pencatat Nikah menurut Undang Undang ini adalah Kantor Urusan Agama. Kantor Urusan Agama adalah suatu lembaga administrasi yang bergerak dalam bidang agama. $^{23}$ Berdasarkan ketentuan ini maka perkawinan belum

${ }^{22}$ Lihat Rachmadi Usman, "Aspek-Aspek Hukum Perorangan dan Keluarga di Indonesia", cet. 1, (Jakarta: Sinar Grafika, 2006), hal. 267.

${ }^{23}$ Wienarsih Imam Subekti dan Sri Soesilawati Mahdi, "Hukum Perorangan dan Kekeluargaan Perdata Barat", (Jakarta: Gitama Jaya Jakarta, 2005), hal. 17. 
dianggap sah secara hukum positif bila belum dicatatkan. Namun demikian ada dua pendapat mengenai maksud dari Pasal 2 ayat (2) ini.

Jika dilihat dari tujuan pencatatan perkawinan, menurut hemat penulis bukan hanya untuk tertib administrasi belaka namun juga untuk memberitahukan pada khalayak bahwa telah terjadi perkawinan. Selain itu dengan pencatatan akan diperoleh akta perkawinan, akta ini merupakan bukti kuat secara yuridis karena dibuat oleh pejabat yang berwenang.

Kedua pendapat para sarjana hukum itu adalah: ${ }^{24}$

Pendapat pertama memisahkan penafsiran Pasal 2 ayat (1) dengan Pasal 2 ayat (2), bahwa perkawinan dianggap sah apabila dilakukan menurut hukum masing-masing agama dan kepercayaannya itu, sedangkan pencatatan perkawinan adalah syarat administrasi saja, sehingga dilakukan atau tidak, tidak berpengaruh pada sahnya perkawinan.

Sedangkan pendapat kedua, para sarjana hukum yang menafsirkan Pasal 2 ayat (1) dan Pasal 2 ayat (2) itu bukan saja dari segi yuridis semata yaitu sahnya perkawinan, tetapi dikaitkan secara sosiologis yang menurut mereka Pasal 2 ayat (1) dan Pasal 2 ayat (2) tidak dapat dipisahkan, merupakan rangkaian kesatuan. Sehingga perkawinan yang tidak dicatatkan walaupun telah memenuhi syarat agama dan kepercayaannya adalah tidak sah.

Wasit Aulawi sependapat dengan pendapat kedua, bahwa bunyi Pasal 2 ayat (1) dan ayat (2) merupakan satu kesatuan yang tidak boleh dipisahkan. Perintah pencatatan perkawinan itu sangat positif, hal ini diatur oleh pemerintah demi terwujudnya kesejahteraan dan kebahagiaan bagi rakyatnya. ${ }^{25}$ Sedangkan Wahyono Darmabrata berpendapat pencatatan perkawinan semata-mata hanya merupakan perbuatan administratif, dan tidak mempengaruhi sah atau tidaknya perkawinan. ${ }^{26}$

${ }^{24}$ Lihat M. Idris Ramulyo, "Tinjauan Beberapa Pasal Undang Undang Nomor 1 Tahun 1974 Dari Segi Hukum Perkawinan Islam", cet. 1, (Jakarta: Ind-Hill-Co, 1985), hal. 231.

${ }^{25}$ Lihat Wasit Aulawi, Pernikahan Harus Melibatkan Masyarakat, Mimbar Hukum, No. 28 tahun VII (September-Oktober 1996), hal. 23-24.

${ }^{26}$ Wahyono Darmabrata, "Tinjauan Undang Undang No. 1 Tahun 1974 Tentang Perkawinan Beserta Undang Undang dan Peraturan Pelaksanaannya", cet. 3, (Jakarta: Rizkita, 2008), hal. 64. 
Tujuan dilakukannya pencatatan ini adalah agar khalayak tahu bahwa telah terjadi perkawinan dan dengan dilakukannya pencatatan maka terbit akta nikah. Akta nikah ini merupakan bukti kuat dan sempurna bahwa telah terjadi perkawinan antara pihak yang identitasnya tercantum dalam akta tersebut. Akta ini dikatakan dapat dijadikan bukti yang kuat dan sempurna karena dibuat oleh pejabat yang berwenang.

Menurut hukum Islam perkawinan merupakan muamalah. Jika kita merujuk pada Q.S. al-Baqarah (2): 282 Allah berfirman :

Apabila kamu melakukan utang piutang untuk waktu
yang ditentukan, hendaklah kamu
menuliskannya.....Dan hendaklah disaksikan dua saksi
laki-laki diantara kamu... ${ }^{27}$

Dalam ayat ini memang yang disebutkan adalah utang piutang, namun dapat diqiyaskan ${ }^{28}$ dengan perkawinan. Karena utang piutang juga merupakan muamalah. Jika hutang piutang yang diperjanjikan biasanya benda, maka dalam perkawinan yang diperjanjikan adalah ikatan antara manusia yang melangsungkan perkawinan. Perkawinan sendiri merupakan perjanjian yang kuat dan kokoh yang memerlukan kepastian hukum dan mempunyai akibat hukum yang luas, sehingga sudah selayaknya dicatat. Pencatatan ini akan memberi perlindungan hukum bagi para pihak, misalnya jika di masa yang akan datang salah satu pihak mengingkari perkawinan tersebut, maka pihak lain dapat membuktikan bahwa benar telah terjadi perkawinan dengan menunjukkan bukti akta nikah mereka. Dengan demikian dapat dikatakan bahwa pencatatan perkawinan dilakukan untuk mencegah mudharat yang akan terjadi bila rumah tangga tidak harmonis lagi. Bukankah lebih baik menghindari kemudharatan.

Mengingat pentingnya pencatatan perkawinan bagi suami isteri untuk pembuktian telah terjadi perkawinan dan menjadikan sahnya perkawinan menurut hukum negara sehingga hak-hak isteri dan anak dapat terlindungi, pemerintah sangat memperhatikan hal ini. Hal ini terlihat pada Rancangan Undang

${ }^{27}$ Departemen Agama Republik Indonesia, Op. Cit., hal. 59-60.

${ }^{28}$ Qiyas adalah menyamakan hukum suatu hal yang tidak terdapat ketentuannya di dalam al-Qur'an dan as-Sunnah atau al-Hadistdengan hal (lain) yang hukumnya disebut dalam al-Qur'an dan sunnah Rasul karena karena persamaan illat (peneyebab atau alasan) nya. Lihat Mohammad Daud Ali, Op. Cit., hal. 105 
Undang Hukum Terapan Peradilan Agama Bidang Perkawinan, dalam Pasal 4 dikatakan bahwa setiap perkawinan wajib dicatat oleh Pejabat Pencatat Nikah menurut peraturan perundangundangan yang berlaku. Kemudian hal ini ditegaskan kembali dalam Pasal 5 ayat (1) bahwa setiap perkawinan wajib dilangsungkan di hadapan Pejabat Pencatat Nikah dan pada ayat (2) dikatakan bahwa perkawinan yang tidak dilakukan sesuai dengan ketentuan ayat (1) maka tidak mempunyai kekuatan hukum. Kewajiban pencatatan perkawinan ini tidak menjadi syarat sahnya perkawinan menurut hukum Islam, karena dalam Pasal 3 ditentukan perkawinan adalah sah apabila dilakukan menurut hukum Islam. Dalam penjelasan umum butir a dikatakan kewajiban pencatatan perkawinan di hadapan pegawai Pencatat Nikah adalah untuk menjamin ketertiban administrasi perkawinan dan kepastian hukum bagi para pihak yang melangsungkan perkawinan guna membentuk keluarga sakinah. Jadi jika perkawinan itu tidak dicatatkan maka perkawinan itu tetap sah menurut agama asalkan telah memenuhi rukun dan syarat perkawinan.

Namun demikian keadaan ini dikunci dengan ketentuan pidana sebagaimana diatur dalam Pasal 141. Dalam pasal ini diatur bagi setiap orang yang melangsungkan perkawinan tidak di hadapan Pejabat Pencatat Nikah akan dipidana denda paling banyak Rp 6.000.000,- (enam juta rupiah) atau hukuman kurungan paling lama 6 (enam) bulan. Ketentuan pidana dalam rancangan undang-undang ini tidak hanya mengenai pihak yang melangsungkan perkawinan yaitu calon suami dan isteri tapi juga bagi sesorang yang bertindak seolah-olah sebagai Pejabat Pencatat Nikah dan/atau wali hakim sebagaimana dimaksud dalam Pasal 4 dan Pasal 21 dipidana dengan pidana penjara paling lama 3 (tiga) tahun. Menelaah ketentuan-ketentuan di atas jelas sekali pemerintah sangat kuat mewujudkan pencatatan perkawinan. Dengan adanya sanksi ini diharapkan semua perkawinan di Indonesia akan tercatat dan cita-cita tertib administrasi perkawinan akan terwujud dan perlindungan hukum bagi isteri dan anak akan tercapai.

Menurut hemat penulis, pencatatan perkawinan ini sangat penting dan sebaiknya dilaksanakan karena lebih banyak manfaatnya daripada mudharatnya. Pemerintah dalam hal ini dapat berlaku tegas terhadap para pihak yang melangsungkan perkawinan namun tidak dicatat kecuali ada hal-hal khusus yang 
menyebabkan pencatatan tidak dapat dilakukan. Misalnya tempat KUA jauh dan sulit dijangkau dari kediaman mempelai, atau ketiadaan biaya untuk membayar administrasi pernikahan. Alasanalasan inipun harus dibuktikan kebenarannya.

Hal ini penulis kemukakan karena Allahpun dalam Qur'an surah an-Nisaa (4): 59 mengharuskan umat Islam untuk mentaati al-Qur'an, Rasul dan ulil amri atau pemimpin.

\section{Perkawinan di Bawah Tangan}

Perkawinan di bawah tangan dikenal juga dengan istilah kawin siri. Kata siri dalam istilah nikah siri berasal dari bahasa Arab, yaitu sirrun yang berarti rahasia. Melalui akar kata ini, nikah siri berarti sebagai nikah yang dirahasiakan, berbeda dengan nikah pada umumnya yang dilakukan secara terang-terangan (jahri). ${ }^{29}$

Menurut Idris Ramulyo, perkawinan di bawah tangan adalah suatu perkawinan yang dilakukan oleh orang-orang Islam Indonesia, memenuhi baik rukun-rukun maupun syarat-syarat perkawinan, tetapi tidak didaftarkan pada Pejabat Pencatat Nikah, seperti diatur dan ditentukan oleh Undang Undang Perkawinan. ${ }^{30}$ Prof. Wahyono Darmabrata, berpendapat bahwa perkawinan di bawah tangan ialah perkawinan yang dilaksanakan dengan mengabaikan syarat dan prosedur undang-undang, dapat terjadi tidak dilakukan di depan KUA, tetapi dilakukan di depan Pemuka Agama. Perkawinan demikian dapat diartikan sebagai iktikad untuk penyelundupan ketentuan negara yang tertuang dalam undang-undang. ${ }^{31}$ Sedangkan M. Yahya Harahap mengartikan perkawinan di bawah tangan adalah perkawinan yang tidak dicatatkan di Kantor Urusan Agama (KUA) dan Kantor Catatan Sipil $(\mathrm{KCS})^{32}$ yang mana perkawinan tersebut telah memenuhi hal. 22.

${ }^{29}$ Happy Susanto, 'Nikah Siri Apa Untungnya?", cet.1, (Jakarta: Visimedia, 2007),

${ }^{30}$ Idris Ramulyo, "Hukum Perkawinan Islam Suatu Analisis Undang Undang Nomor 1 Tahun 1974 dan Kompilasi Hukum Islam", cet. 4, (Jakarta: Bumi Aksara, 1996), hal. 131.

${ }^{31}$ Wahyono Darmabrata, Op. Cit., hal. 89.

${ }^{32}$ Sesuai dengan keputusan Presiden Nomor 12 Tahun 1983 bagi masyarakat yang beragama selain Islam, pencatatan perkawinan dilakukan di Kantor Catatan Sipil agar 
syarat-syarat dan rukun perkawinan menurut hukum agamanya dan kepercayaannya itu tetapi tidak didaftarkan atau dicatatkan pada Pegawai Pencatat Nikah, seperti yang diatur dan ditentukan dalam Undang Undang Nomor 1 Tahun 1974 Tentang Perkawinan. ${ }^{33}$ Menurut Happy Susanto, perkawinan di bawah tangan adalah bentuk perkawinan yang dilakukan hanya berdasarkan aturan (hukum) agama dan atau adat istiadat tapi tidak diumumkan kepada khalayak umum dan juga tidak dicatatkan secara resmi pada kantor Pegawai Pencatat Nikah, yaitu Kantor Urusan Agama bagi yang beragama Islam dan Kantor Catatan Sipil bagi yang non muslim. ${ }^{34}$

Dari beberapa pendapat tersebut dapat ditarik benang merah pengertian perkawinan di bawah tangan adalah perkawinan yang telah memenuhi aturan agama dan kepercayaannya namun tidak dicatatkan. Perkawinan di bawah tangan ini hanya memenuhi unsur agama dan kepercayaannya namun tidak memenuhi unsur hukum negara.

Perkawinan di bawah tangan sampai saat ini masih terjadi di Indonesia. Pelaku perkawinan di bawah tangan ini bukan dari kalangan berpendidikan rendah dan ekonomi lemah saja, juga dari kalangan yang berpendidikan dan ekonomi menengah ke atas. Faktor- faktor yang menyebabkan terjadinya perkawinan ini beragam seperti untuk menghindari perbuatan zina,sehingga harus disegerakan perkawinannya, dan faktor ekonomi. Mempelai tidak sanggup membayar biaya proses pencatatan perkawinan. Pada umumnya mereka tidak begitu memperdulikan kesahan pekawinan tersebut dilihat dari hukum negara, yang terpenting sah menurut agama dan kepercayaannya itu. Selain kedua alasan tersebut di atas ada juga yang melakukan nikah siri agar dapat melakukan poligami karena calon mempelai pria tidak mendapat izin dari isterinya sebagaimana diamanatkan undang-undang. Dapat juga terjadi karena salah satu pihak masih terikat perjanjian dengan tempatnya bekerja tentang larangan menikah sampai batas waktu yang telah ditentukan perusahaan tersebut. Suami yang sedang dalam proses perceraian dengan isterinya dan yang

diperoleh salinan akta perkawinan yang merupakan akta otentik karena dibuat oleh pejabat yang berwenang sehingga perkawinan tersebut memperoleh kepastian dan kekuatan hukum.

${ }^{33}$ M. Yahya Harahap, "Hukum Perkawinan Nasional", cet. 1, (Medan: CV Zhir Prading Co.Medan, 1975), hal. 38.

${ }^{34}$ Happy Susanto, Op. Cit., hal. 22. 
beranggapan pencatatan perkawinan bukan merupakan perintah agama. $^{35}$

Undang Undang Perkawinan tidak mengenal perkawinan di bawah tangan, karena seperti telah dijelaskan sebelumnya bahwa Pasal 2 ayat (2) undang undang ini mensyaratkan pencatatan perkawinan. Sehingga perkawinan di bawah tangan tidak sah menurut hukum negara walaupun sah menurut hukum agama dan kepercayaannya itu. Perkawinan ini bukan merupakan perbuatan hukum karena tidak mengikuti hukum yang berlaku sehingga perkawinan di bawah tangan tidak mempunyai kekuatan hukum.

Kompilasi Hukum Islam juga mensyaratkan pencatatan perkawinan, namun hanya untuk ketertiban administratif saja, sebagaimana diatur dalam Pasal 5 Kompilasi Hukum Islam menganggap sah perkawinan di bawah tangan jika sudah memenuhi rukun dan syarat perkawinan. Begitu juga dengan Rancangan Undang Undang Hukum Terapan Peradilan Agama Bidang Perkawinan mewajibkan pencatatan perkawinan, bahkan bila melangsungkan perkawinan dan tidak dicatatkan akan terkena sanksi pidana sebagaimana telah dijelaskan sebelumnya.

Majelis Ulama Indonesia melalui Keputusan Ijtima seIndonesia II di Pondok Pesantren Modern Gontor Ponorogo, Jawa Timur pada tanggal 25 - 28 Mei 2006 mengeluarkan fatwa yang menyatakan : Pernikahan di bawah tangan hukumnya sah kalau terpenuhinya syarat dan rukun nikah, tetapi haram jika menimbulkan mudharat atau dampak negatif. Menurut penulis fatwa ini tidak tegas menyatakan sah karena masih ada kata-kata "... jika tidak menimbulkan mudharat atau dampak negatif". Jika kita melihat mudharatnya perkawinan di bawah tangan tentu ada. Perkawinan ini tidak sah menurut negara, tidak ada bukti kuat dan sempurna bagi suami dan isteri bahwa mereka telah menikah. Dan bila pengertian dari kata-kata tersebut melihat dari niat baik para pihak untuk menikah, membentuk keluarga yang sakinah, mawaddah dan rahmah, tentu tidak dapat dijamin kelangsungannya. Dapat saja setelah menikah beberapa waktu terjadi perpecahan diantara suami isteri, baru akan timbul masalah. Dapat dipahami sulit bagi Majelis Ulama Indonesia untuk mewajibkan pencatatan perkawinan sebagai syarat sahnya

${ }^{35}$ Lihat R.B. Priyo Sembodo, Nikah Siri dalam Tinjauan Psikososial, Makalah disampaikan dalam seminar NIkah Siri Ditinjau Dari Hukum Syar'I, Psikososial, dan Hukum Positif, Yogyakarta, 2003, hal. 3. 
perkawinan, mengingat keterbatasan-keterbatasan yang ada pada umat Islam, seperti rendahnya pemahaman tentang pentingnya pencatatan perkawinan, masih ada daerah-daerah yang terpencil jauh dari KUA dan sulit menjangkaunya, serta faktor finansial yaitu mahalnya biaya pernikahan yang dilakukan di hadapan Pegawai Pencatat Nikah sebagaimana dialami umat muslim di Indonesia. Selain itu adanya pendapat bahwa pencatatan perkawinan bukan merupakan syarat namun hanya prosedur administratif belaka.

Perkawinan di bawah tangan atau nikah siri ini karena tidak sah menurut hukum negara tentu membawa akibat hukum, terutama sangat merugikan isteri dan anak. Adapun akibat hukum dari perkawinan ini adalah perkawinan ini dianggap tidak sah karena tidak dicatatkan pada Kantor Urusan Agama dan Kantor Catatan Sipil, sehingga seakan-akan perkawinan itu tidak pernah terjadi. Akibat dari tidak sahnya perkawinan ini maka :

a. Isteri bukan merupakan isteri sah, sehingga tidak mempunyai hak untuk mendapatkan nafkah, tempat tinggal, harta gono gini juga harta warisan.

b. Anak bukan merupakan anak yang sah. Karena menurut Pasal 42 Undang Undang perkawinan dan Pasal 99 Kompilasi Hukum Islam anak yang sah adalah anak yang dilahirkan dalam atau sebagai akibat perkawinan yang sah. Selanjutnya pada Pasal 43 ayat (1) Undang Undang Perkawinan dan Pasal 100 Kompilasi Hukum Islam anak yang dilahirkan di luar pernikahan hanya mempunyai hubungan perdata dengan ibunya dan keluarga ibunya. Sehingga anak kehilangan hak atas nama atau nasab bapaknya, nafkah lahir maupun batin, tempat tinggal, pendidikan, dan warisan jika bapaknya meninggal dunia. Anak tidak mempunyai hubungan hukum dengan bapaknya. $\mathrm{Hal}$ ini akan berdampak pada jiwa anak karena ia dianggap anak luar kawin, apalagi jika ayah tidak mau bertanggung jawab dan tidak menjalankan fungsinya sebagai bapak.

Dari uraian di atas jelas terlihat kerugian-kerugian yang dialami oleh isteri dan anak pada perkawinan di bawah tangan. Perkawinan ini tidak mempunyai kekuatan hukum. Walaupun pencatatan perkawinan bukan merupakan rukun dan syarat sahnya perkawinan, namun berdasarkan ijtihad dapat dikatakan sebagai syarat sahnya muamalah, merujuk pada Q.S. al-Baqarah (2): 282,sehingga dapat dikatakan pencatatan ini wajib hukumnya. Jika dilihat dari mudharat yang 
ditimbulkan akibat tidak dilakukannya pencatatan perkawinan maka pencatatan perkawinan sangat penting dan sangat dianjurkan untuk dilakukan agar hak-hak isteri dan anak dapat terlindungi dan terpenuhi.

Mengingat pentingnya akta nikah sebagi alat bukti telah terjadi pernikahan yang sah bagi suami isteri terutama isteri dan anak, bagi mereka yang belum mencatatkan perkawinannya hukum Islam memberi jalan keluar dengan melakukan itsbat nikah. Itsbat nikah adalah penetapan perkawinan oleh Pengadilan Agama tentang keabsahan perkawinan suami isteri yang perkawinannya tidak dicatatkan atau tidak dapat dibuktikan.

Itsbat nikah diatur dalam Pasal 7 ayat (2) Kompilasi Hukum Islam, yaitu dalam hal perkawinan tidak dapat dibuktikan dengan Akta Nikah, dapat diajukan itsbat nikahnya ke Pengadilan Agama.

Pengajuan itsbat nikah ini menurut Pasal 7 ayat (3) Kompilasi Hukum Islam terbatas untuk hal-hal:

1. Adanya perkawinan dalam rangka penyelesaian perceraian.

2. Hilangnya akta nikah.

3. Adanya keraguan tentang sah atau tidaknya salah satu syarat perkawinan.

4. Adanya perkawinan yang terjadi sebelum berlakunya Undang Undang Perkawinan.

5. Perkawinan yang dilakukan oleh mereka yang tidak mempunyai halangan perkawinan menurut Undang Undang No. 1 tahun 1974.

Ketentuan itsbat nikah ini juga diatur dalam Rancangan Undang Undang Hukum Terapan Peradilan Agama namun alasan pengajuan itsbat nikah lebih sempit daripada ketentuan sebagaimana yang termaktub dalam Kompilasi Hukum Islam. Dalam RUU ini alasan pengajuan itsbat nikah hanya karena hilangnya Akta Nikah dan Kutipannya. Kemudian dalam Ketentuan Peralihan Pasal 151 ditentukan untuk perkawinan yang tidak memenuhi ketentuan sebagaimana diatur dalam UU ini wajib dilakukan itsbat nikah ke Pengadilan selambat-lambatnya 5 tahun setelah terjadinya perkawinan. Ketentuan ini sangat memberatkan karena itsbat hanya dapat dilakukan oleh pasangan yang menikah lima tahun sebelumnya. Bagaimana dengan pernikahan yang dilakukan lebih dari lima tahun yang lalu? Sebaiknya kata-kata "...selambat-lambatnya 5 (lima) setelah terjadinya perkawinan" diubah menjadi "...selambat-lambatnya 5 (lima) tahun sejak peraturan ini diundangkan". Sehingga dapat menolong pihakpihak yang melakukan nikah siri untuk memperoleh kepastian dan kekuatan hukum perkawinannya. 


\section{Penutup}

Nikah siri atau nikah di bawah tangan karena tidak dicatatkan pada Pegawai Pencatat Nikah maka tidak sah secara hukum negara namun sah menurut hukum agama bila dilaksanakan sesuai dengan rukun dan syarat perkawinan. Akibat dari tidak sahnya nikah siri menurut hukum negara dan karena tidak dicatat maka perkawinan ini dianggap tidak ada maka nikah siri ini sangat merugikan bagi isteri dan anak.

Baik isteri maupun anak tidak dapat menuntut hak-haknya melalui Pengadilan apabila terjadi perceraian. Isteri tidak dapat menuntut hak nafkah, tempat tinggal, harta gono gini dan juga harta waris dari suaminya. Begitu juga anak, anak hanya mempunyai hubungan perdata dengan ibunya, ia tidak mempunyai hak nasab, nafkah, pemeliharaan dan pendidikan dari bapaknya juga hak waris atas harta peninggalan bapaknya.

Untuk mengatasi hal ini Islam memberi jalan keluar yaitu dengan cara mengajukan itsbat nikah ke Pengadilan Agama, sehingga nikah siri ini menjadi tercatat dan mempunyai kepastian dan kekuatan hukum. 


\section{Daftar Pustaka}

\section{Buku}

Abdullah, Abdul Gani. Pengantar Kompilasi Hukum Islam Dalam Tata Hukum Indonesia, Cet. 1. Jakarta: Gema Insan Press, 1994.

Al-Fauzan, Syaikh Shalih bin Fauzan. Ringkasan Fikih Lengkap, Terj. Asmuni. Cet. 1. Jakarta: darul Falah, 2005.

Ali, M. Daud. Hukum Islam; Pengantar Ilmu Hukum dan Tata Hukum Islam di Indonesia, Jakarta: PT. Raja Grafindo Persada, 2004.

Ali, Yunasril dan Taufik Abdullah, dkk. Perkawinan, Ensiklopedi Tematis Dunia Islam, Jakarta: Ichtiar Baru van Hoeve.

Al-Jurjawi, Syaikh 'Ali Ahmad. Hikmah di Balik Hukum Islam, Jakarta: Mustaqim, 2003.

Al-Malibary, Syeikh Zainuddin bin Abdul Azis. Fatchul Mu'in, Jilid 3. Terj. Ally As'ad. Kudus: Menara Kudus, 1979.

Al-Qur'an dan Terjemahannya, Yayasan Penyelenggara Penterjemah AlQur'an, Surabaya: Mahkota Surabaya, 1989.

As-Salman, Musa'id bin Abdillah. Indahnya Syariat Islam atau Asror asySyariah Min I'lam al-Muwaqi'in, terj. Widyan Wahyudi. Jakarta: Pustaka At-Tazkia, 2007.

Asy Syaukani, al Imam Muhammad. Terjemah Naitul Authar, Jilid 5,6 terjemahan Mu'ammmal Hamidy, et.Al. Surabaya: PT. Bina Ilmu, 1993.

Asyarie, Sukmajaya dan Rosy Yusuf. Indeks Al-Qur'an, Cet.1. Bandung: Pustaka, 1984.

Aulawi, Waid. "Pernikahan Harus Melibatkan Masyarakat", Mimbar Hukum, No. 28 Tahun VII, 1996.

Ayyub, Syaikh Hasan. Fikih Keluarga, Terj. M. Abdul Ghoffar. Cet. 1. Jakarta: Pustaka Al-Kautsar.

Azhary, M. Tahir. Bunga Rampai Hukum Islam (Kumpulan Tulisan), Cet. 1. Jakarta: Ind. Hill-Co, Agustus1992.

Darmabrata, Wahyono dan Surini Ahlan Sjarif. Hukum Perkawinan dan Keluarga di Indonesia, Jakarta: Badan Penerbit FHUI, 2004. 
Darmabrata, Wahyono. "Undang-undang Perkawinan, Undang-undang No. 1 Tahun 1974 Mengenai Pengaturan Dan Masalah Yang Perlu Diperhatikan", Pidato Pengukuhan Guru Besar Tetap Universitas Indonesia. Depok: 29 Maret 2003.

Dept. Agama RI. AlQur'an dan Terjemahannya, Jakarta: Cahaya Qur'an, 2006.

Djubaedah, Neng et.al. Hukum Perkawinan Islam di Indonesia, Jakarta: PT. Hecca Mitra Utama, 2003.

Harahap, M. Yahya. Hukum Perkawinan Nasional, Cet. 1. Medan.

Jumantoro, Totok dan Samsul Munir Amin. Kamus Ilmu Usul Fikih, Cet. 1. s.l: Penerbit Amzah, 2005.

Prodjodikoro, Wirjono. Hukum Perkawinan di Indonesia, Cet. 9. Bandung: Sumur Bandung, 1991.

Ramulyo, Idris. Tinjauan Beberapa Pasal Undang-undang Nomor 1 tahun 1974 dari Segi Hukum Perkawinan Islam, Ed. Rev. Jakarta: Ind HillCo,1990.

Shihab, M. Quraish. Wawasan Al-Qur'an, Bandung: Mizan, 2004.

Susanto, Happy. Nikah Siri Apa Untungnya?, Cet. 1. Jakarta: Visimedi, 2007.

Syarifuddin, Amir. Hukum Perkawinan Islam di Indonesia; Antara Fiqh, Munakahat dan Undang-undang Perkawinan, Cet. 1. Jakarta: Prenada Media, 2006.

Thalib, Sajuti. Hukum Kekeluargaan Indonesia Berlaku bagi Umat Islam, Cet. 5. Jakarta: Penerbit Universitas Indonesia (UI Press), 1986.

\section{Peraturan Perundang-Undangan}

Indonesia. Undang Undang tentang Perkawinan, UU Nomor 1 Tahun 1974 LN Nomor 1 Tahun 1974.

. Peraturan Pemerintah Tentang Pelaksanaan Undang-undang Perkawinan, PP No. 9 Tahun 1975 LN No. 12 Tahun 1975. TLN 2050.

Kompilasi Hukum Islam di Indonesia, Instruksi Presiden RI Nomor 1 Tahun 1991. 